\title{
Identification and Characterization of Citrus tristeza virus Isolates Breaking Resistance in Trifoliate Orange in California
}

\author{
Raymond K. Yokomi, Vijayanandraj Selvaraj, Yogita Maheshwari, Maria Saponari, Annalisa Giampetruzzi, \\ Michela Chiumenti, and Subhas Hajeri
}

First, second, and third authors: U.S. Department of Agriculture-Agricultural Research Service, San Joaquin Valley Agricultural Sciences Center, 9611 South Riverbend Avenue, Parlier, CA 93648-9757; fourth and sixth authors: Institute for Sustainable Plant Protection, National Research Council, Sezione di Bari, Via Amendola 165/A, 70126 Bari, Italy; fifth author: Department of Soil Plant and Food Science, University of Bari, Via Amendola 165/A, 70126 Bari, Italy; and seventh author: Citrus Pest Detection Program, Central California Tristeza Eradication Agency, 22847 Road 140, Tulare, CA 93274-9367.

Accepted for publication 15 February 2017.

ABSTRACT

\begin{abstract}
Most Citrus tristeza virus (CTV) isolates in California are biologically mild and symptomless in commercial cultivars on CTV tolerant rootstocks. However, to better define California CTV isolates showing divergent serological and genetic profiles, selected isolates were subjected to deep sequencing of small RNAs. Full-length sequences were assembled, annotated and trifoliate orange resistance-breaking (RB) isolates of CTV were identified. Phylogenetic relationships based on their full genomes placed three isolates in the RB clade: CA-RB-115, CA-RB-AT25, and CA-RB-AT35. The latter two isolates were obtained by aphid transmission from Murcott and Dekopon trees, respectively, containing CTV mixtures. The California RB isolates were further distinguished into two subclades. Group I included CA-RB-115 and CA-RB-AT25 with $99 \%$ nucleotide sequence identity with RB type strain NZRB-G90; and group II included CA-RB-AT35 with 99 and 96\% sequence identity with Taiwan Pumelo/SP/T1 and HA18-9, respectively. The RB
\end{abstract}

phenotype was confirmed by detecting CTV replication in graft-inoculated Poncirus trifoliata and transmission from $P$. trifoliata to sweet orange. The California RB isolates induced mild symptoms compared with severe isolates in greenhouse indexing tests. Further examination of $570 \mathrm{CTV}$ accessions, acquired from approximately 1960 and maintained in planta at the Central California Tristeza Eradication Agency, revealed $16 \mathrm{RB}$ positive isolates based on partial $p 65$ sequences. Six isolates collected from 1992 to 2011 from Tulare and Kern counties were CA-RB-115-like; and 10 isolates collected from 1968 to 2010 from Riverside, Fresno, and Kern counties were CA-RBAT35-like. The presence of the RB genotype is relevant because $P$. trifoliata and its hybrids are the most popular rootstocks in California.

Additional keywords: CTV genotypes, next-generation sequencing, stem pitting.
Citrus tristeza virus (CTV) has diverse strains that range in virulence from asymptomatic to those that cause great economic losses to citrus cultivars like sweet orange and grapefruit (Moreno et al. 2008). The genome of CTV is comprised of $\sim 19.3-\mathrm{kb}$ RNA with 12 open reading frames (ORFs) (Karasev et al. 1995). CTV is graft and aphid transmissible (Moreno et al. 2008). Nucleotide sequences generated from amplicons produced by polymerase chain reaction (PCR) using primers developed to various noncontiguous regions of the CTV genome have differentiated CTV isolates into genotypes with general association with the phenotypes (Hilf et al. 2005; Roy et al. 2010). By analyzing full-length sequences of CTV isolates, Dawson et al. (2015) determined that CTV isolates belonged to seven sequence groups (T36, VT, T3, resistancebreaking (RB), T68, T30, and HA16-5), but cautioned that isolates in these groups contained variations in virulence and should not be used in defining a phenotype. The CTV RB isolates were first identified in New Zealand by Dawson and Mooney (2000). Subsequently, Harper et al. (2010) reported five New Zealand RB isolates from full-length CTV genome sequences. RB isolates of CTV are unique because they replicate and systemically infect trifoliate orange (Poncirus trifoliata (L.) Raf.), immune to other strains of CTV. RB isolates have now

Corresponding author: R. K. Yokomi; E-mail address: ray.yokomi@ars.usda.gov

*The $\boldsymbol{e}$-Xtra logo stands for "electronic extra" and indicates that five supplementary figures and one supplementary table are published online.

This article is in the public domain and not copyrightable. It may be freely reprinted with customary crediting of the source. The American Phytopathological Society, 2017. been identified in Hawaii (Melzer et al. 2010), Puerto Rico (Roy et al. 2013), Dominican Republic (Matos et al. 2013), and South Africa (Scott et al. 2013).

The Central California Tristeza Eradication Agency (CCTEA) has been testing citrus trees in Central California for CTV infection since 1963 by biological indexing and enzyme-linked immunosorbent assay (ELISA) with a CTV coat protein-based polyclonal antibody (Gottwald et al. 2002). In 2009, the CCTEA adopted screening CTV isolates with MCA13 monoclonal antibody (MAb) Permar et al. 1990) to distinguish potentially severe strains of CTV from nonreactive CTV isolates (Barnier et al. 2010). We examined isolates from Central California and found that the prevalent strain is a T30 genotype and is mild in virus indexing tests and essentially symptomless on CTV tolerant or resistant rootstocks (Yokomi and DeBorde 2005; Yokomi et al. 2010a). Moreover, a rapid screen for putative genotype classification was developed using TaqMan probes in reverse transcriptionquantitative PCR (RT-qPCR) (Yokomi et al. 2010b). Therefore, MCA13-reactive isolates further confirmed by TaqMan probes and selected isolates examined by deep sequencing of small RNAs by next-generation sequencing (NGS). Three isolates were found that belonged to the RB sequence group. These results and its ramifications are presented herein since trifoliate orange and its hybrids are the most popular rootstocks used in California for citrus production.

\section{MATERIALS AND METHODS}

Virus isolates and molecular characterization. CTV was detected in leaf extracts from field trees by ELISA using a broadspectrum CTV polyclonal antiserum (Nikolaeva et al. 1995) or by immunocapture RT-qPCR (Saponari et al. 2008; Yokomi and DeBorde 
2005). Subsequently, a second ELISA was performed using MAb MCA13 (Permar et al. 1990) and MCA13-reactive isolates were further characterized using different strain-specific molecular markers (Hilf et al. 2005; Roy et al. 2013; Yokomi et al. 2010b). Isolates reacting with the strain-specific probe T36NS (Yokomi et al. 2010b), potentially associated to an RB genotype, were specifically selected for molecular and biological assays. Infected trees found to harbor multiple CTV genotypes were subjected to aphid transmission and receptor plants infected with RB-like genotypes were used in this study. Specifically, parent trees of Dekopon (P108) and Murcott sources were found to contain a mixture of CTV populations, therefore, strains were separated by aphid (Aphis gossypii, cotton biotype) transmission to Mexican lime (Citrus aurantifolia) or Alemow (C. macrophylla) and graft inoculated and maintained in Madam Vinous (MV) sweet orange (Yokomi and DeBorde 2005). Aphid-transmitted isolates were selected from over 100 individual aphid transmission replicates (five aphids/receptor plant) per field isolate and identified with an AT in its name. The isolates are described in Table 1 and includes the county where the isolate was collected.

For the molecular tests, approximately $150 \mathrm{mg}$ of fresh tissue of young leaves, midribs, and bark was ground in extraction bags (Bioreba, Switzerland) using a blunt hammer or mallet. Total nucleic acids (TNA) were extracted by CTAB method (Doyle and Doyle 1990) and used directly in one-step RT-qPCR assays. Putative CTV genotypes were determined with reaction to TaqMan probes designed in the coat protein intergenic region $(\mathrm{CPi})$ between p25 (major CP) and p27 (minor CP) and designated as CPi-VT3, -T36, and -T36NS (Saponari and Yokomi 2010; Yokomi et al. $2010 \mathrm{~b}$ ). Briefly, $1 \mu \mathrm{l}$ target at $200 \mathrm{ng} / \mu \mathrm{l}$ was added to a final volume of $22-\mu 1$ reaction that contained $300 \mathrm{nM}$ forward and reverse primers each and $150 \mathrm{nM}$ of the genotype-specific probes. Each qPCR reaction was conducted in triplicate wells and each test was repeated three times. Relative CTV titer was assessed by cycle quantification $(\mathrm{Cq})$ of the labeled probe. Conventional PCR was also conducted using the $p 65$ primer pairs designed to detect RB isolates (Roy et al. 2013).

Small RNA sequencing and genome assembly. To obtain the full genome of the selected potential RB strains, a cDNA library was constructed using the small RNA (sRNA) fraction purified from $1 \mathrm{~g}$ of symptomatic leaves ( $\mathrm{Lu}$ et al. 2007) collected from infected
MV seedlings and Illumina sequenced (reads of 50 cycles singleend). The resultant datasets were processed for adaptor trimming, and ribosomal and transfer RNA sequences were removed by UEA siRNA toolkit (Moxon et al. 2008). The filtered 18 to 26 siRNA derived sequence reads were assembled de novo into larger contigs with a k-mer of 17 using Velvet Software 0.7.31 (Zerbino and Birney 2008), and contigs mapping to CTV genome were obtained.

Gaps from NGS were filled by sequencing cDNA fragments amplified with specific primers designed for genome walking. Amplicons were cloned with the Strataclone PCR Cloning Kit (Agilent Technologies, Santa Clara) and a minimum of four clones per fragment were subjected to Sanger sequencing. The $5^{\prime}-$ and $3^{\prime}-$ termini sequences were obtained by rapid amplification of cDNA ends using FirstChoice RLM Kit (Invitrogen, Carlsbad, CA) and the completed full-length sequences of the three California CTV isolates were deposited in NCBI (Table 1).

Phylogenetic and evolutionary analysis. The complete genomes of the CTV sequences were aligned using ClustalW. The nucleotide sequence identities of the California RB isolates with the 55 fulllength CTV sequences available in NCBI were obtained using BioEdit program version 7.2.5. Neighbor network reconstruction of full-length CTV genome sequences and the three California RB CTV isolates were carried out using SplitsTree4 Version 4.14.4 (Huson and Bryant 2006). Maximum parsimony bootstrap consensus tree was obtained using the Subtree-Pruning-Regrafting (SPR) algorithm (Nei and Kumar 2000) with search level 1 in which the initial trees were obtained by the random addition of sequences (10 replicates). The percentage of replicate trees in which the associated taxa clustered together in the bootstrap test (1,000 replicates) are shown next to the branches (Felsenstein 1985). Evolutionary analyses were conducted in MEGA7 (Kumar et al. 2016).

Full exploratory recombination analysis was performed in RDP4 (Martin et al. 2015) using the RDP (Martin and Rybicki 2000), BootScan (Salminen et al. 1995), SiScan (Gibbs et al. 2000), Chimera (Posada and Crandall 2001), Geneconv (Padidam et al. 1999), MaxChi (Smith 1992), and 3Seq (Boni et al. 2007) methods to generate a consensus of regions that may be recombinant in origin. Recombination events for the RB CTV isolates that were identified by four or more models with $P$ values $(P<0.01)$ were considered. Events where parental sequences could not be identified were discarded.

TABLE 1. Californian Citrus tristeza virus (CTV) isolates harboring a resistance-breaking (RB) genotype

\begin{tabular}{|c|c|c|c|c|c|c|c|}
\hline CTV isolates & $\begin{array}{c}\text { GenBank } \\
\text { accession no. }\end{array}$ & $\begin{array}{c}\text { Year } \\
\text { collected }\end{array}$ & $\begin{array}{l}\text { Collection } \\
\text { location }\end{array}$ & County & Original host & CTV Genotype $(\mathrm{s})^{\mathrm{y}}$ & Target sequences \\
\hline CA-RB-115 & KU361340 & 1994 & Lindsay & Tulare & Citrus sinensis 'Navel' & $\mathrm{RB}$ & Full genome $(19,256 \mathrm{nt})$ \\
\hline CA-RB-AT25 & KU356770 & 2009 & Fillmore & Ventura & C. reticulata 'Murcott' & $\mathrm{RB}$ & Full genome $(19,255 \mathrm{nt})$ \\
\hline CA-RB-AT35 & KU358530 & 2008 & Navelencia & Fresno & C. reticulata 'Dekopon' & $\mathrm{RB}$ & Full genome $(19,270 \mathrm{nt})$ \\
\hline SY558z & KY364012 & 1968 & Riverside & Riverside & C. sinensis 'Waialua sweet orange' & $\mathrm{RB}+\mathrm{T} 30+\mathrm{VT}$ & Partial p65 \\
\hline 00438 & KY364006 & 2000 & Navelencia & Fresno & C. reticulata 'Dekopon' & $\mathrm{RB}+\mathrm{T} 30+\mathrm{VT}$ & Partial p65 \\
\hline 00448 & KY369764 & 2000 & Navelencia & Fresno & C. reticulata 'Dekopon' & $\mathrm{RB}+\mathrm{T} 30+\mathrm{VT}+\mathrm{S} 1$ & Partial p65 \\
\hline 00449 & KY369765 & 2000 & Navelencia & Fresno & C. reticulata 'Dekopon' & $\mathrm{RB}+\mathrm{T} 30+\mathrm{VT}$ & Partial p65 \\
\hline 00451 & KY364007 & 2000 & Navelencia & Fresno & C. reticulata 'Dekopon' & $\mathrm{RB}+\mathrm{T} 30+\mathrm{VT}+\mathrm{S} 1$ & Partial p65 \\
\hline 00453 & KY364008 & 2000 & Navelencia & Fresno & C. reticulata 'Dekopon' & $\mathrm{RB}+\mathrm{T} 30+\mathrm{VT}$ & Partial p65 \\
\hline 00454 & KY364011 & 2000 & Navelencia & Fresno & C. reticulata 'Dekopon' & $\mathrm{RB}+\mathrm{T} 30+\mathrm{VT}+\mathrm{S} 1$ & Partial p65 \\
\hline 252 & KY364009 & 1994 & Ivanhoe & Tulare & C. sinensis 'Navel' & $\mathrm{RB}+\mathrm{T} 30+\mathrm{S} 1$ & Partial p65 \\
\hline 96142 & KY364010 & 1996 & Ivanhoe & Tulare & C. reticulata $\times$ C. paradisi 'Minneola' & $\mathrm{RB}+\mathrm{T} 30+\mathrm{S} 1$ & Partial p65 \\
\hline 109 & KY369761 & 1994 & Lindsay & Tulare & C. sinensis 'Navel' & $\mathrm{RB}+\mathrm{T} 30$ & Partial p65 \\
\hline 11666 & KY369760 & 2011 & Ducor & Tulare & C. sinensis 'Navel' & $\mathrm{RB}+\mathrm{T} 30$ & Partial p65 \\
\hline 10620 & KY369759 & 2010 & Richgrove & Kern & C. sinensis 'Navel' & $\mathrm{RB}+\mathrm{T} 30+\mathrm{VT}$ & Partial $p 65$ \\
\hline 10619 & KY369762 & 2010 & Richgrove & Kern & C. sinensis 'Navel' & $\mathrm{RB}+\mathrm{T} 30+\mathrm{VT}$ & Partial p65 \\
\hline 206 & KY369758 & 1996 & Edison & Kern & C. sinensis 'Navel' & $\mathrm{RB}+\mathrm{T} 30+\mathrm{S} 1$ & Partial p65 \\
\hline 274 & KY364005 & 1994 & Edison & Kern & C. sinensis 'Navel' & $\mathrm{RB}+\mathrm{T} 30+\mathrm{S} 1$ & Partial p65 \\
\hline 279 & KY369763 & 1996 & Edison & Kern & C. sinensis 'Navel' & $\mathrm{RB}+\mathrm{T} 30+\mathrm{S} 1$ & Partial p65 \\
\hline
\end{tabular}

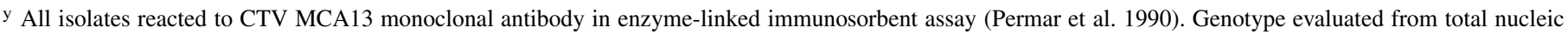
acid extraction and reverse transcription-quantitative PCR (RT-qPCR) using strain-discriminating TaqMan probes (Yokomi et al. 2010b). All isolates reacted with the T36NS probe. S1 is an undescribed new CTV sequence group and S1-specific primers were used in RT-PCR for detection (R. K. Yokomi, unpublished data).

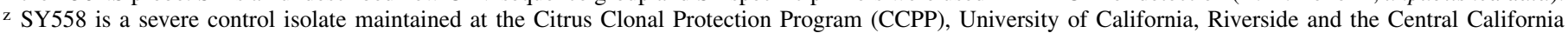
Tristeza Eradication Agency (CCTEA), Tulare. The original host was Waialua sweet orange from Honolulu, HI, imported to Riverside in 1914 and was found to be infected with SY558 in 1968 by the CCPP, (T. Siebert, personal communication, University of California, Riverside). 
Confirmation of the $\mathbf{R B}$ isolates. To confirm presence of the CTV RB isolates, MV plants infected with the CA-RB isolates were graft-inoculated onto P. trifoliata. At 2, 6, and 12 months postinoculation (mpi), RNA extracts from roots and leaves of test plants were analyzed for CTV detection by RT-qPCR using the universal TaqMan probe for CTV coat protein (Saponari et al. 2008) as well as the T36NS probe. After 6 months, bark from $P$. trifoliata plants were graft-inoculated onto healthy plants of MV for further confirmation of replication and transmissibility of the virus to other citrus cultivars.

Biological indexing and statistical analysis. A standard citrus host range was used to evaluate severity of these isolates in comparison with known severe CTV isolates. A weighted cumulative $(\Sigma)$ disease index (DI) was used as described by Garnsey et al. (1987). Specifically, each character (leaf cupping, vein clearing, stem pitting [SP], stunting, and seedling yellows [SY]) was scored from $0=$ no symptoms to $3=$ severe. The host plants were Mexican lime (ML), MV grafted on sour orange (SO), Duncan grapefruit (DGF), SO, and MV with each host's cumulative symptom score weighted per host as $\mathrm{x} 1, \mathrm{x} 2, \mathrm{x} 3, \mathrm{x} 4$, and $\mathrm{x} 5$, respectively, and summed per isolate (Garnsey et al. 1987).

SAS PROC GLIMMIX was used for making comparisons among interaction of means. Isolate $\times$ host measures were done in a randomized complete block framework with blocks = reps. Each isolate had four replicates per host. The Tukey-Kramer grouping for each CTV isolate DI was separated by least square means (SAS Institute 2013).

CCTEA CTV isolate collection. The CCTEA collection represents archived CTV isolates from samples taken from commercial field trees in California from 1963 to the present. This collection also included control isolates from the Citrus Clonal Protection Program (CCPP), University of California, Riverside, $\mathrm{CA}$. To determine the historical presence of RB isolates in California, 570 accessions of the in-planta CTV at the CCTEA were genotyped using strain-discriminating TaqMan probes (Yokomi et al. 2010b) and 70 accessions reacted to the T36NS probe. Since some of the CCTEA collections were found to be a duplicate collection (same or similar strain collected from adjacent trees in the same grove and year), only selected T36NS positive samples (representing different locations and collection times) were subjected to RT-PCR using the p65 primer pair and products sequenced.

\section{RESULTS}

Serological and molecular screening of CTV isolates. A total of 19 CTV isolates were found to react both with the selective MAb MCA13 in ELISA, and with the strain-specific TaqMan probe T36NS in RT-qPCR (Table 1). These isolates also produced a 627bp product when subjected to conventional PCR with the $p 65$ primer pair. Three of these isolates were selected for further studies: (i) genome characterization through deep sequencing; and (ii) grafting on $P$. trifoliata to correlate their genetic relatedness to the RB isolates with their capability to move and multiply in the resistant rootstock.
Deep sequencing of small RNA and complete genome reconstruction. The dataset of clean reads (18 to $26 \mathrm{nt}$ after filtering) were found to contain between 18 and $33 \%$ of CTVderived sequences (with 'zero' mismatch). The CTV sRNAs of 21 to $22 \mathrm{nt}$ represented the largest fractions of sRNAs, with those of (+) polarity being in moderate excess (Supplementary Fig. S1). Regardless to their size, CTV sRNAs covered the entire viral genome but reads at the $3^{\prime}$ - and $5^{\prime}$-termini were overrepresented for CA-RB-AT25 and CA-RB-115; whereas that of CA-RB-AT35 was more evenly distributed (Supplementary Fig. S2).

Full-length sequences of the test isolates were then compared with those of other full-length CTV sequence groups from the NCBI database to determine nucleotide sequence identities. The highest sequence identities were in the RB sequence group and ranged from 95.9 to $96.3 \%$ (Table 2). Phylogenetic and evolutionary analyses based on two methods showed that the California T36NS-reactive isolates fell in the same major phylogenetic clade containing isolates of different origins and previously characterized as RB (Fig. 1; Supplementary Fig. S3), while the other genotypes were clustered in agreement with previous reports (Harper 2013; Varveri et al. 2015). Within the major clade containing the RB isolates, two subclades (groups) could be distinguished, with the Californian isolates positioned in group I (CA-RB-115 and CA-RB-AT25) and group II (CA-RBAT35). CA-RB-115 and CA-RB-AT25 had 99.5 and $98.7 \%$ identity with NZRB-G90, respectively, and were on the same branch with other New Zealand RB isolates; whereas CA-RB-AT35 was on a separate subclade, showing the highest sequence identities $(99.3$ to $99.5 \%$ ) with the isolate B390-5 and Taiwan-Pum/SP/T1. This subclade also included the isolate HA18-9.

Similar results were obtained when phylogenetic analysis was performed individually for the major CTV ORFs, with the three California isolates consistently clustering together with the RB isolates. For $p 27, p 25, p 20$, and $p 23$, the three California isolates were positioned on two distinct branches, with CA-RB-115 and CA-RB-AT25 showing the highest sequence identity with the isolate NZRB-G90, and the isolate CA-RB-AT35 with the isolates B390-5 and Taiwan-Pum/SP/T1 (Supplementary Fig. S4A to D). This phylogenetic divergence became more prominent for the genes encompassing the 3 'end terminal region (i.e., the $p 27, p 25, p 23$, and $p 20)$. In these cases, the RB isolates fell into the same two distinct phylogenetic clades as with the full-length sequences: RB group I including B301, NZRB-M12, NZRB-G90, NZRB-TH28, NZRBM17, NZRB-TH30, CA-RB-AT25, and CA-RB-115; and RB group II including B390-5, Taiwan-Pum/SP/T1, HA18-9, and CA-RB-AT35. The intra-group evolutionary divergence was $3.21 \%$ (SE 0.105) and $2.21 \%$ (SE 0.075 ) for RB group I and group II, respectively. The two groups also showed a divergence of $5.44 \%$ (SE 0.15).

Recombination analysis. Recombination analyses using RDP4 of the available 60 full-length CTV genomes revealed traces of recombination in all isolates. Six recombination events specific to RB isolates were identified (Table 3) and genomic positions are shown in Supplementary Figure S5. RB isolates retained ancestral recombination event with Western group of VT isolates in the partial RdRP-p61

TABLE 2. Mean nucleotide identities between the complete genome of Citrus tristeza virus strain groups and the California resistance-breaking (RB) isolates

\begin{tabular}{|c|c|c|c|c|c|c|c|c|c|c|c|}
\hline Isolate & A18 & VT & T3 & $\mathrm{T} 30$ & T68 & HA16-5 & T36 & $\mathrm{RB}$ & SY568 & CA-RB-AT35 & CA-RB-AT25 \\
\hline VT & 90.8 & & & & & & & & & & \\
\hline T3 & 89.1 & 92.4 & & & & & & & & & \\
\hline T30 & 87.9 & 90.5 & 89.8 & & & & & & & & \\
\hline HA16-5 & 82.5 & 82.2 & 82.5 & 81.4 & 85.7 & & & & & & \\
\hline T36 & 82.5 & 77.2 & 76.8 & 78.6 & 76.7 & 76.7 & & & & & \\
\hline $\mathrm{RB}$ & 82.7 & 78.2 & 77.7 & 78.8 & 77.6 & 77.9 & 90.3 & & & & \\
\hline SY568 & 90.6 & 94.4 & 90.6 & 93.9 & 86.1 & 81.8 & 79.0 & 79.2 & & & \\
\hline CA-RB-115 & 82.7 & 78.4 & 78.0 & 79.3 & 77.9 & 77.5 & 89.9 & 96.2 & 79.6 & 94.1 & 98.9 \\
\hline
\end{tabular}


(event 1). RB isolates from group I retained $\mathrm{S} 1$ strain-like sequences (R. K. Yokomi, unpublished data) in the partial p61 to $p 20$ ORFs (event 2). The RB isolates from group I including NZRB-M12, NZRB-TH28, NZRB-G90, CA-RB-115, and CA-RB-AT25 and the S1 strain shared an event similar to T36-like sequences in p61-p25 ORFs (event 3). Some RB isolates from group I and II including B390-5, Taiwan Pum/SP/T1, CA-RB-AT35, NZRB-TH30, and NZRB-M17 had a T36-like sequence at the beginning of ORF 1a (events 4 and 5). The NZRB-TH30 isolate had a specific event at the $3^{\prime}$ end of ORF 1a through partial RDRP similar to RB itself from NZRB-TH28 (event 6) (Table 3).

Confirmation of the RB phenotype. Extracts from roots and bark of $P$. trifoliata inoculated with CTV isolates CA-RB-115, CARB-AT25, and CA-RB-AT35 were positive by RT-qPCR with Cq

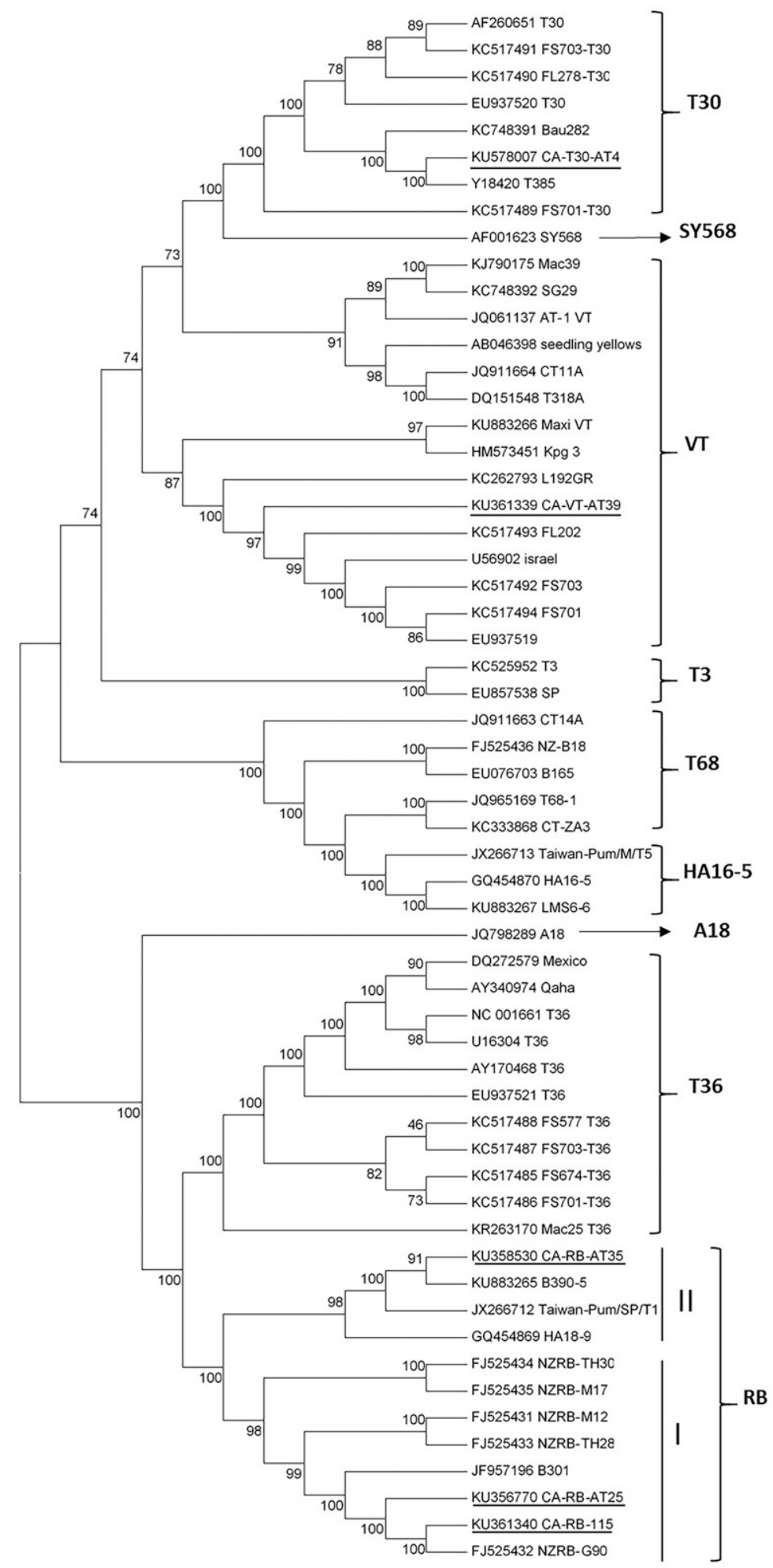

Fig. 1. Maximum parsimony phylogeny for the complete genome of Citrus tristeza virus (CTV). The percentage of replicate trees in which the taxa clustered together in the bootstrap test (1,000 replicates) are shown next to the branches. Evolutionary analyses conducted in MEGA7. The resistance-breaking (RB) subclades (groups) I and II are also indicated. GenBank accession number for each isolate is included in the figure. The three RB California CTV isolates used in this study are underlined. 
values at 2 mpi ranging from 20.3 to 27.5 ; at 6 mpi ranging from 17.0 to 26.1 ; and at 12 mpi ranging from 21.5 to 27.6 . Healthy controls remained negative for CTV throughout the test. As further proof for virus replication, the CA-RB isolates from $P$. trifoliata were inoculated onto MV seedlings and, after $3 \mathrm{mpi}$, were detected in leaf tissue extracts from MV seedlings with $\mathrm{Cq}$ values ranging from 18.3 to 27 by RT-qPCR.

Biological indexing. The three $\mathrm{RB}$ isolates were mild in a citrus host range indexing test (Table 4) with a $\Sigma$ DI ranging from 2.5 to 5.4. The $\Sigma$ DI for CA-RB-115 and CA-RB-AT35 were not significantly different from the healthy control; whereas CA-RB-AT25 had a slightly higher score but was in the same statistical group with the other RB isolates. The VT isolates P108A and RH, in comparison, had a $\Sigma$ DI ranging from 47.3 to 50.4 , which was significantly different from the $\mathrm{RB}$ isolates $(P \leq 0.05)$. The RB isolates did not induce SY or SP in indicator plants; whereas P108A and RH induced severe SY and some SP as indicated by higher DIs in DGF, MV, and SO (Table 4).

RB isolates in the CCTEA collection. In addition to the three fully sequenced RB isolates, 16 isolates from the CCTEA in planta CTV collection were found that belonged in the RB group based on sequences from amplified p65 products (KY364005 to KY364012; KY369758 to KY369765) (Table 1). Most of these isolates were mixtures with T30 and VT variants. The earliest RB component was found in SY558 (KY364012), an accession isolated in 1968 from a Waialua sweet orange tree imported from Honolulu, HI in 1914 by the CCPP that was grown in the University of California-Riverside Citrus Variety Collection (CVC). In the 1970s, the entire CVC was subjected to thermotherapy to eliminate all graft-transmissible virus and virus-like agents (T. Siebert, personal communication, University of California, Riverside). The other 15 $\mathrm{RB}$ isolates were collected from different locations in Fresno, Tulare, and Kern counties from 1994 to 2011 (Table 1). Phylogenetic analysis of the partial p65 (HSP70) sequences showed that the Central Valley RB isolates separated into two subclades: one harboring the isolates that were related to CA-RB-115 (group I), and the other was related to CA-RB-AT35 (group II) (Fig. 2). The CA-RB-115-like isolates were predominantly mixtures with T30 variants, whereas the CA-RB-A35-like isolates were predominately mixtures with T30 and VT variants.

\section{DISCUSSION}

A diverse group of California CTV isolates react with MCA13 MAb. Some of these isolates are virulent and others are mild in greenhouse bio-indexing tests (Yokomi et al. 2010a). Therefore, a reliable method to discriminate CTV strains including those that react with MCA13 was developed utilizing TaqMan probes in RT-qPCR by Yokomi et al. (2010b). The T36NS probe was found useful to identify putative RB isolates. This was combined with RT-PCR using the $p 65$ primers and sequencing the amplified products to confirm the genetic relationship of these isolates. Sequencing was needed because some California VT isolates also amplified VT products with $p 65$ primers in the same genome region (12,248 to 12,844$)$.

sRNA analysis showed that 21 to 22 nt CTV sRNAs were the largest fraction present and major hot spots of sRNAs were observed

TABLE 3. Location and origin of recombination events found in resistance-breaking (RB) Citrus tristeza virus isolates

\begin{tabular}{|c|c|c|c|c|c|c|c|c|c|c|c|}
\hline Event & Start-end & $\begin{array}{l}\text { Recombinant } \\
\text { sequence(s) }\end{array}$ & $\begin{array}{l}\text { Minor parental } \\
\text { sequence }(\mathrm{s})\end{array}$ & $\begin{array}{l}\text { Major parental } \\
\text { sequence }(s)\end{array}$ & RDP & GENE-CONV & Bootscan & Maxchi & Chimaera & SiSscan & 3 Seq \\
\hline 1 & $10,656-14,206$ & $\mathrm{RB}^{\mathrm{v}}$ & $\begin{array}{l}\text { Western VT } \\
\text { group }^{\mathrm{w}}\end{array}$ & T36 & $1.85 \mathrm{E}-37$ & $\mathrm{NS}^{\mathrm{x}}$ & $3.00 \mathrm{E}-10$ & $3.01 \mathrm{E}-26$ & $1.35 \mathrm{E}-23$ & $1.15 \mathrm{E}-14$ & $1.46 \mathrm{E}-11$ \\
\hline 2 & $14,620-18,096$ & $\mathrm{RB}$ group $\mathrm{I}^{\mathrm{y}}$ & $\mathrm{S} 1^{\mathrm{z}}$ & $\begin{array}{l}\text { Taiwan-Pum/SP/T1; } \\
\text { CA-RB-AT35; } \\
\text { B390-5 }\end{array}$ & $9.48 \mathrm{E}-143$ & $6.19 \mathrm{E}-52$ & $1.72 \mathrm{E}-141$ & $7.94 \mathrm{E}-27$ & $5.46 \mathrm{E}-12$ & 8.09E-28 & $2.62 \mathrm{E}-11$ \\
\hline 3 & $14,534-16,745$ & $\begin{array}{l}\text { NZRB-M12; } \\
\text { NZRB-TH28; } \\
\text { CA-RB-115; } \\
\text { CA-RB-AT25; } \\
\text { NZRB-G90 } \\
\text { and } \mathrm{S1}^{\mathrm{z}}\end{array}$ & T36 & T3; Maxi_VT & $1.88 \mathrm{E}-26$ & NS & NS & $8.21 \mathrm{E}-05$ & $1.00 \mathrm{E}-06$ & $2.53 \mathrm{E}-20$ & $8.74 \mathrm{E}-12$ \\
\hline 4 & $19,206-3,666$ & $\begin{array}{l}\text { B390-5; } \\
\text { CA-RB-AT35; } \\
\text { Taiwan-Pum/SP/T1 }\end{array}$ & T36 & HA18-9 & $1.05 \mathrm{E}-87$ & $1.41 \mathrm{E}-44$ & $2.06 \mathrm{E}-70$ & $2.60 \mathrm{E}-28$ & $3.38 \mathrm{E}-28$ & $2.76 \mathrm{E}-30$ & $2.91 \mathrm{E}-12$ \\
\hline 5 & $19,301-3,346$ & NZRB-TH30/M17 & T36 & NZRB-TH28/M12 & $2.44 \mathrm{E}-96$ & $3.01 \mathrm{E}-37$ & $8.82 \mathrm{E}-95$ & $3.87 \mathrm{E}-41$ & $1.64 \mathrm{E}-36$ & 4.19E-26 & $8.74 \mathrm{E}-12$ \\
\hline 6 & $8,974-10,636$ & NZRB-TH30 & NZRB-TH28 & NZRB-M17 & $2.37 \mathrm{E}-18$ & $1.14 \mathrm{E}-15$ & $6.02 \mathrm{E}-19$ & $1.76 \mathrm{E}-10$ & $4.75 \mathrm{E}-11$ & $1.99 \mathrm{E}-13$ & $2.91 \mathrm{E}-12$ \\
\hline
\end{tabular}

$\mathrm{v}$ RB indicates all RB isolates.

w Harper (2013).

${ }^{x}$ NS indicates no significant $P$ value was recorded for this recombination event using this RDP4 software $(P<0.01)$.

y RB group I includes B301, NZRB-M12, NZRB-G90, NZRB-TH28, NZRB-M17, NZRB-TH30, CA-RB-AT25, and CA-RB-115.

${ }^{\mathrm{z}} \mathrm{S} 1$ is a new genotype (R. K. Yokomi, unpublished data).

TABLE 4. Biological indexing of selected MCA13-reactive Citrus tristeza virus (CTV) isolates to compare virulence by evaluating a disease index (DI) per citrus host and cumulative total ( $\Sigma \mathrm{DI})$

\begin{tabular}{|c|c|c|c|c|c|c|c|}
\hline \multirow[b]{2}{*}{ Isolate } & \multicolumn{5}{|c|}{ Average DI per citrus host ${ }^{y}$} & \multirow[b]{2}{*}{$\Sigma$ DI per isolate ${ }^{\mathrm{z}}$} & \multirow[b]{2}{*}{ Sequence group } \\
\hline & ML & $\mathrm{SW} / \mathrm{SO}$ & DGF & SO & MV & & \\
\hline Healthy control & 0.0 & 0.00 & 0.0 & 0.0 & 0.00 & $0.0 \mathrm{c}$ & $\ldots$ \\
\hline CA-RB-115 & 0.0 & 0.0 & 0.0 & 0.00 & 2.5 & $2.5 \mathrm{bc}$ & RB \\
\hline CA-RB-AT25 & 0.1 & 4.0 & 0.0 & 0.0 & 1.3 & $5.4 \mathrm{~b}$ & RB \\
\hline P108A (Dekopon) & 8.1 & 6.8 & 18.6 & 0.8 & 13.1 & $47.3 \mathrm{a}$ & VT \\
\hline RH & 9.2 & 3.8 & 30.7 & 3.0 & 3.8 & $50.4 \mathrm{a}$ & VT \\
\hline
\end{tabular}

y Symptoms scored individually per symptom category from $0=$ no symptom to $3=$ severe. The categories were as follows: ML $=$ Mexican lime cumulative score $\mathrm{x} 1$ for leaf cupping, vein clearing, stem pitting (SP) and stunting; SW/SO = sweet orange/sour orange cumulative score x2 for SP and stunting; DGF = Duncan grapefruit cumulative score $\mathrm{x} 3$ for SY, SP, and stunting; SO = sour orange cumulative score $\mathrm{x} 4$ for SY and stunting; and MV = Madam Vinous cumulative score $\mathrm{x} 5$ for SP and stunting. The $\Sigma$ DI is the DI sum of all hosts per isolate (Garnsey et al. 1987). Each host had three replications per isolate.

${ }^{\mathrm{z}}$ Means with the same letter are not statistically different $(P \leq 0.05)$. 
in the 3 '-termini and an accumulation along the 5 '-terminal region. These findings were in agreement with findings from T318A, a severe strain of CTV from Spain (Ruiz-Ruiz et al. 2011).

Deep sequencing of sRNAs and full-length sequences of the three putative RB isolates and phylogenetic analysis with 55 other fulllength CTV isolates removed all ambiguities in identifying CA-RB isolates. In addition, these analyses grouped CA-RB isolates in two different subclades. Group I included CA-RB-115 and CA-RBAT25 along with NZ RB-G90 and the other New Zealand RB isolates; and group II which included CA-RB-AT35 with Taiwan Pum/SP/T1, South African isolate B390-5, and Hawaiian isolate HA18-9.

CA-RB-AT35-like All $\mathrm{RB}$ are clustered together except for the non RB isolate HA16-5

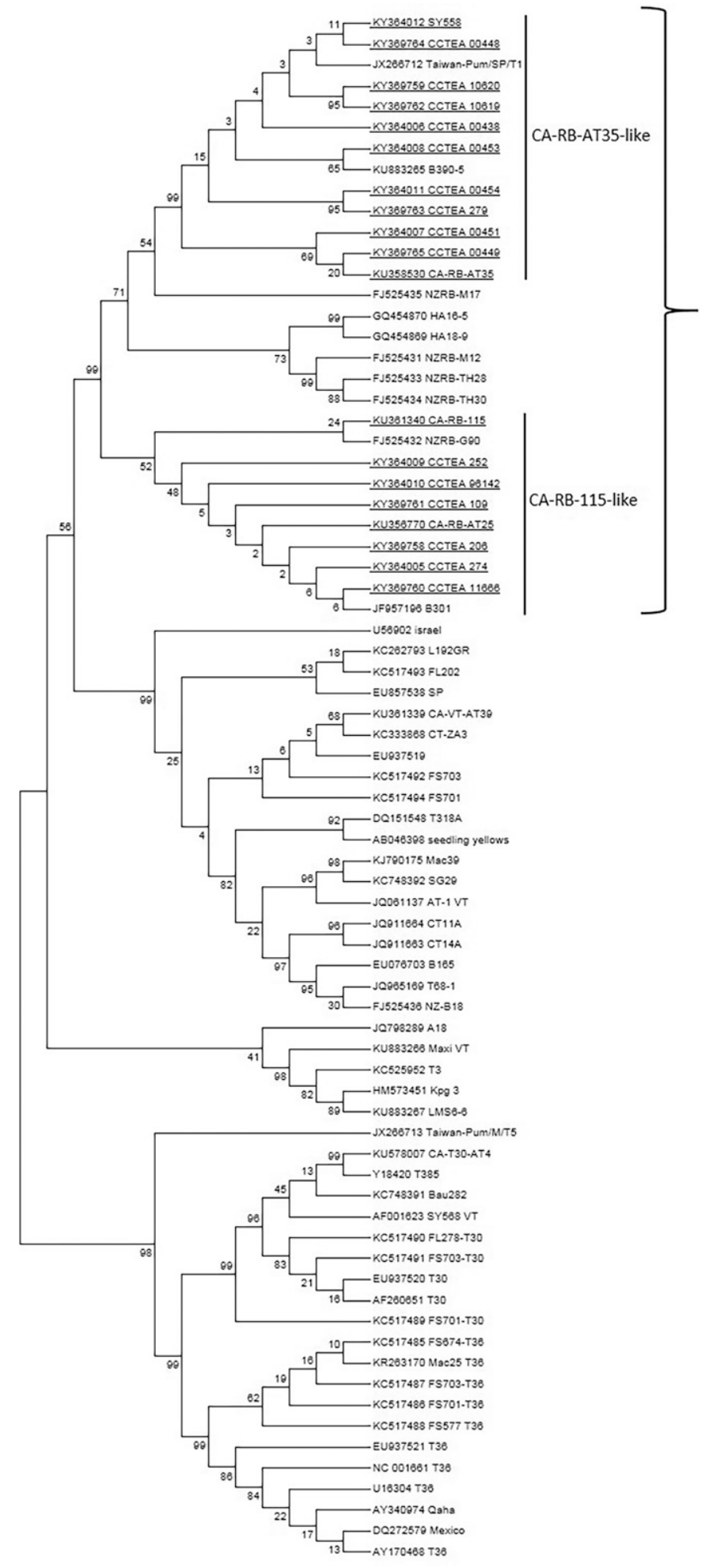

Fig. 2. Phylogenetic analysis of the partial p65 gene sequence of resistance-breaking (RB) isolates of Citrus tristeza virus (CTV) collected in California. There were 16 field RB isolates that fell into either group I or group II isolate subclade of the RB phylogeny in comparison with CA-RB-115 (KU361340) (group I) and CA-RB-AT35 (KU358530) (group II). The maximum parsimony tree was constructed using the MEGA7 program. The percentage of replicate trees in which the associated taxa clustered together in the bootstrap test (1,000 replicates) are shown next to the branches. Branch lengths are proportional to the genetic distances. Accession number for each isolate is included in the figure. The California RB isolates are underlined. 
Harper (2013) observed an ancestral recombination event in the partial p65 gene from a VT-like isolate. In our study, an ancestral recombination event occurred in the partial RdRP-p61 ORFs from the Western group of VT isolates, rather than all the other VT isolates. The group I isolates in a separate subclade in the phylogenetic analysis had a specific recombination event in p61-p25 ORFs similar to an S1 strain (R. K. Yokomi, unpublished data). Cook et al. (2016) developed primer pairs for two groups of RB isolates that grouped New Zealand RB isolates in either group I or group II. In the current report, however, all New Zealand RB isolates were in group I. The phylogenetic and recombination analyses supported at least two groups of RB isolates exist in California.

Six field isolates from Tulare and Kern counties had CA-RB-115like (group I) sequences in the partial $p 65$ and were predominantly a mixture with the T30 genotype. The SY558 isolate and all Dekopon field CTV isolates contained CA-RB-AT35-like (group II) components in the partial p65 region and were mixtures with T30 and VT. CA-RB-AT35 originated from Dekopon, a Japanese mandarin cultivar that was illegally introduced into California (Polek 2000). The parental Dekopon isolate had a severe SY and SP phenotype but contained a mixture of genotypes (Yokomi et al. 2010a). Aphid transmission of the Dekopon isolate separated CA-RB-AT35 isolate in the RB group II. Interestingly, HA18-9 was reported as an RB isolate from Hawaii (Melzer et al. 2010), which also fell in group II in the present study. The Taiwan Pum/SP/T1 strain was also a group II member and was derived by aphid transmission from the stem pitting CTV-D isolate in Pummelo ( $\mathrm{Su} \mathrm{1981)} \mathrm{but} \mathrm{apparently} \mathrm{did}$ not induce symptoms in Mexican lime (Tsai et al. 1993). Three other group II CA-RB-AT35-like field isolates in California were found in Kern County, approximately $120 \mathrm{~km}$ south of Navelencia. Whether the RB isolates in CCTEA collections represent introductions or resulted from recombination remains speculative. However, these findings may have some biological significance since the group II isolates examined may have had origins from the Asian Pacific region, with the exception of three group II isolates from Kern County having unknown origins. Moreover, plants infected with RB group II isolates in the present study were coinfected with VT, which likely had a role in the isolate's virulence. The RB isolates reacted with MCA13 and with the T36 NS TaqMan probe and were mild and did not induce CTV decline or stem pitting symptoms in grapefruit or sweet orange. The isolates systemically infected $P$. trifoliate and fit the RB phenotype as reported by Dawson and Mooney (2000). P. trifoliate is known to be immune to a wide range of CTV isolates and is a popular rootstock to prevent tristeza decline (Garnsey et al. 1998). As previously mentioned, RB strains have been described from various regions (Harper et al. 2010; Matos et al. 2013; Melzer et al. 2010; Roy et al. 2013; Scott et al. 2013) and is now known to be present in California. With regard to CTV susceptibility by $P$. trifoliata, Harper et al. (2014) examined the tropism of CTV and found a T68 and a VT isolate that infected only roots of $P$. trifoliata. However, the California RB isolates in the present study infected both roots and bark of trifoliate orange. This is significant because trifoliate orange and its hybrids are the most popular rootstocks in California. Moreover, a mild CTV strain that replicates in the scion and roots of cicitrus on trifoliate orange or hybrid rootstocks may be useful to express antimicrobial peptides against the bacterial agent associated with Huanglongbing (HLB) (also known as greening) or RNA interference against the Asian citrus psyllid, vector of the HLB pathogen (Dawson and Folimonov 2013; Hajeri et al. 2014), in roots and scion of citrus including those on trifoliate rootstock treated with the modified RB CTV vector.

\section{ACKNOWLEDGMENTS}

We thank R. DeBorde and C. Crockett of the United States Department of Agriculture-Agricultural Research Service, San Joaquin Valley Agricultural Sciences Center, Parlier, CA for technical assistance; and G. Vidalakis, Director
CCPP, University of California, Riverside and T. J. Siebert, Museum Scientist, Citrus Variety Collection, University of California, Riverside, who provided historical facts about CTV isolate SY558. This work was supported in part by grants from the California Citrus Research Board (5300-138 and 5300-166) and the Tulare County Pest Control District. Mention of trade names or commercial products in this publication is solely for the purpose of providing specific information and does not imply recommendation or endorsement by the U.S. Department of Agriculture. USDA is an equal opportunity provider and employer.

\section{LITERATURE CITED}

Barnier, J., Grafton-Cardwell, B., and Polek, M. 2010. Citrus tristeza virus (CTV): Then and now. Citrograph 1:16-23.

Boni, M. F., Posada, D., and Feldman, M. W. 2007. An exact nonparametric method for inferring mosaic structure in sequence triplets. Genetics 176: 1035-1047.

Cook, G., van Vuuren, S. P., Breytenbach, J. H. J., Burger, J. T., and Maree, H. J. 2016. Expanded strain-specific RT-PCR assay for differential detection of currently known Citrus tristeza virus strains: A useful screening tool. J. Phytopathol. 164:847-851.

Dawson, T. E., and Mooney, P. A. 2000. Evidence for trifoliate resistance breaking isolates of Citrus tristeza virus in New Zealand. Pages 69-76 in: Proc. 14th Conf. Int. Org. Citrus Virol. J. V. da Graça, R. F. Lee, and R. K. Yokomi, eds. IOCV, University of California, Riverside.

Dawson, W. O., Bar-Joseph, M., Garnsey, S. M., and Moreno, P. 2015. Citrus tristeza virus: Making an ally from an enemy. Annu. Rev. Phytopathol. 53: 137-155.

Dawson, W. O., and Folimonov, S. Y. 2013. Virus-based transient expression vectors for woody crops: A new frontier for vector design and use. Annu. Rev. Phytopathol. 51:321-337.

Doyle, J. J., and Doyle, J. L. 1990. Isolation of plant DNA from fresh tissue. Focus 12:13-15.

Felsenstein, J. 1985. Confidence limits on phylogenies: An approach using the bootstrap. Evolution 39:783-791.

Garnsey, S. M., Gottwald, T. R., and Yokomi, R. K. 1998. Control strategies for Citrus tristeza virus. Pages 639-658 in: Plant Virus Disease Control. A. Hadidi, R. Khetarpal, and H. Koganezawa, eds. American Phytopathological Society, St. Paul, MN.

Garnsey, S. M., Gumpf, D. J., Roistacher, C. N., Civerolo, E. L., Lee, R. F., Yokomi, R. K., and Bar-Joseph, M. 1987. Toward a standardized evaluation of the biological properties of Citrus tristeza virus (CTV) isolates. Phytophylactica 19:151-157.

Gibbs, M. J., Armstrong, J. S., and Gibbs, A. J. 2000. Sister-Scanning: A Monte Carlo procedure for assessing signals in recombinant sequences. Bioinformatics 16:573-582.

Gottwald, T. R., Polek, M., and Riley, K. M. 2002. History, present incidence, and spatial distribution of Citrus tristeza virus in the California Central Valley. Pages. 83-94 in: Proc. 15th Conf. Int. Org. Citrus Virol. N. Duran-Villa, R. G. Milne, and J. V. da Graça, eds. IOCV, University of California, Riverside.

Hajeri, S., Killiny, N., El-Mohtar, C., Dawson, W. O., and Gowda, S. 2014. Citrus tristeza virus-based RNAi in citrus plants induces gene silencing in Diaphorina citri, a phloem-sap sucking insect vector of citrus greening disease (Huanglongbing). J. Biotechnol. 176:42-49.

Harper, S. J. 2013. Citrus tristeza virus: Evolution of complex and varied genotypic groups. Front. Microbiol. 4:93.

Harper, S. J., Cowell, S. J., Robertson, C. J., and Dawson, W. O. 2014. Differential tropism in roots and shoots infected by Citrus tristeza virus. Virology 460-461:91-99.

Harper, S. J., Dawson, T. E., and Pearson, M. N. 2010. Isolates of Citrus tristeza virus that overcome Poncirus trifoliata resistance comprise a novel strain. Arch. Virol. 155:471-480.

Hilf, M. E., Mavrodieva, V. A., and Garnsey, S. M. 2005. Genetic marker analysis of a global collection of isolates of Citrus tristeza virus: Characterization and distribution of CTV genotypes and association with symptoms. Phytopathology 95:909-917.

Huson, D. H., and Bryant, D. 2006. Application of phylogenetic networks in evolutionary studies. Mol. Biol. Evol. 23:254-267.

Karasev, A. V., Boyko, V. P., Gowda, S., Nikolaeva, O. V., Hilf, M. E., Koonin, E. V., Niblett, C. L., Cline, K., Gumpf, D. J., Lee, R. F., Garnsey, S. M., Lewandowski, D. J., and Dawson, W. O. 1995. Complete sequence of the Citrus tristeza virus RNA genome. Virology 208:511-520.

Kumar, S., Stecher, G., and Tamura, K. 2016. MEGA7: Molecular Evolutionary Genetics Analysis version 7.0 for bigger datasets. Mol. Biol. Evol. 33:1870-1874.

Lu, C., Meyers, B. C., and Green, P. J. 2007. Construction of small RNA cDNA libraries for deep sequencing. Methods 43:110-117. 
Martin, D., and Rybicki, E. 2000. RDP: Detection of recombination amongst aligned sequences. Bioinformatics 16:562-563.

Martin, D. P., Murrell, B., Golden, M., Khoosal, A., and Muhire, B. 2015. RDP4: Detection and analysis of recombination patterns in virus genomes. Virus Evol. 1:1-5.

Matos, L. A., Hilf, M. E., Cayetano, X. A., Feliz, A. O., Harper, S. J., and Folimonova, S. Y. 2013. Dramatic change in Citrus tristeza virus populations in the Dominican Republic. Plant Dis. 97:339-345.

Melzer, M. J., Borth, W. B., Sether, D. M., Ferreira, S., Gonsalves, D., and Hu, J. S. 2010. Genetic diversity and evidence for recent modular recombination in Hawaiian Citrus tristeza virus. Virus Genes 40:111-118.

Moreno, P., Ambrós, S., Albiach-Marti, M., Guerri, J., and Peña, L. 2008. Citrus tristeza virus: A pathogen that changed the course of the citrus industry. Mol. Plant Pathol. 9:251-268.

Moxon, S., Schwach, F., MacLean, D., Dalmay, T., Studholme, D. J., and Moulton, V. 2008. A toolkit for analyzing large-scale plant small RNA datasets. Bioinformatics 24:2252-2253.

Nei, M., and Kumar, S. 2000. Molecular Evolution and Phylogenetics. Oxford University Press, New York.

Nikolaeva, O. V., Karasev, A. V., Gumpf, D. J., Lee, R. F., and Garnsey, S. M. 1995. Production of polyclonal antisera to the coat protein of Citrus tristeza virus expressed in Escherichia coli: Application for immunodiagnosis. Phytopathology 85:691-694.

Padidam, M., Sawyer, S., and Fauquet, C. M. 1999. Possible emergence of new geminiviruses by frequent recombination. Virology 265:218-225.

Permar, T. A., Garnsey, S. M., Gumpf, D. J., and Lee, R. F. 1990. A monoclonal antibody that discriminates strains of Citrus tristeza virus. Phytopathology 80:224-228.

Polek, M. 2000. Report to the Agricultural Commissioners of Fresno and Tulare Counties on the status of Citrus tristeza virus infestation in SE Fresno County. Central California Tristeza Agency, Tulare, CA.

Posada, D., and Crandall, K. A. 2001. Evaluation of methods for detecting recombination from DNA sequences: Computer simulations. Proc. Natl. Acad. Sci. 98:13757-13762.

Roy, A., Ananthakrishnan, G., Hartung, J. S., and Brlansky, R. H. 2010. Development and application of a multiplex reverse transcription polymerase chain reaction assay for screening a global collection of Citrus tristeza virus isolates. Phytopathology 100:1077-1088.

Roy, A., Choudhary, N., Hartung, J. S., and Brlansky, R. H. 2013. The prevalence of the Citrus tristeza virus trifoliate resistance breaking genotype among Puerto Rican isolates. Plant Dis. 97:1227-1234.

Ruiz-Ruiz, S., Navarro, B., Gisel, A., Peña, L., Navarro, L., Moreno, P., Di Serio, F., and Flores, R. 2011. Citrus tristeza virus infection induces the accumulation of viral small RNAs (21-24-nt) mapping preferentially at the 3'-terminal region of the genomic RNA and affects the host small RNA profile. Plant Mol. Biol. 75:607-619.

Salminen, M. O., Carr, J. K., Burke, D. S., and McCutchan, F. E. 1995. Identification of breakpoints in intergenotypic recombinants of HIV type 1 by bootscanning. AIDS Res. Hum. Retroviruses 11:1423-1425.

Saponari, M., Keremane, M., and Yokomi, R. K. 2008. Quantitative detection of Citrus tristeza virus in citrus and aphids by real-time reverse transcription-PCR (TaqMan). J. Virol. Methods 147:43-53.

Saponari, M., and Yokomi, R. K. 2010. Use of the coat protein (CP) and minor $\mathrm{CP}$ intergene sequence to discriminate severe strains of Citrus tristeza virus in three U.S. CTV isolate collections. Pages 43-57 in: Proc. 17th Conf. Int. Org. of Citrus Virol. M. E. Hilf, R. G. Milne, L. W. Timmer, and J. V. da Graça, eds. IOCV, University of California, Riverside.

SAS Institute. 2013. SAS Online Doc ${ }^{\circledR}$ 9.4. SAS Institute Inc., Cary, NC.

Scott, K. A., Hlela, Q., Zablocki, O., Read, D., Van Vuuren, S., and Pietersen, G. 2013. Genotype composition of populations of grapefruit-crossprotecting Citrus tristeza virus strain GFMS12 in different host plants and aphid-transmitted sub-isolates. Arch. Virol. 158:27-37.

Smith, M. J. 1992. Analyzing the mosaic structure of genes. J. Mol. Evol. 34: 126-129.

$\mathrm{Su}$, H.-J. 1981. A tristeza virus strain causing dwarf of pomelo and grapefruit. Pages 423-426 in: Intern. Soc. Citriculture. K. Matsumoto, C. Oogaki, I. Kozaki, K. Kadoya, F. Mizutani, and E. Yuda, eds. ISC, Tokyo, Japan.

Tsai, M.-C., Su, H.-J., and Garnsey, S. M. 1993. Comparative study on stempitting strains of CTV in the Asian countries. Pages 16-19 in: Proc. 12th Conf. Int. Org. of Citrus Virol. P. Moreno, J. V. da Graca, and L. W. Timmer, eds. IOCV, University of California, Riverside.

Varveri, C., Olmos, A., Pina, J. A., Marroquin, C., and Cambra, M. 2015. Biological and molecular characterization of a distinct Citrus tristeza virus isolate originating from a lemon tree in Greece. Plant Pathol. 64:792-798.

Yokomi, R. K., and DeBorde, R. L. 2005. Incidence, transmissibility, and genotype analysis of Citrus tristeza virus (CTV) isolates from CTV eradicative and non-eradicative districts in central California. Plant Dis. 89: 859-866.

Yokomi, R. K., Polek, M., and Gumpf, D. J. 2010a. Transmission and spread of Citrus tristeza virus in Central California. Pages 151-165 in: Citrus tristeza virus Complex and Tristeza Diseases. A. V. Karasev and M. E. Hilf, eds. American Phytopathological Society, St. Paul, MN.

Yokomi, R. K., Saponari, M., and Sieburth, P. J. 2010b. Rapid differentiation and identification of potential severe strains of Citrus tristeza virus by realtime reverse transcription-polymerase chain reaction assays. Phytopathology 100:319-327.

Zerbino, D. R., and Birney, E. 2008. Velvet: Algorithms for de novo short read assembly using de Bruijn graphs. Genome Res. 18:821-829. 